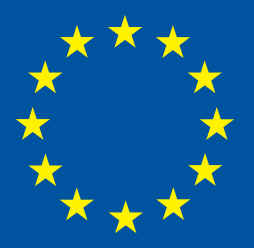

Shared Vision, Common Action: A Stronger Europe

\title{
A Global Strategy for the
}

European Union's Foreign And Security Policy

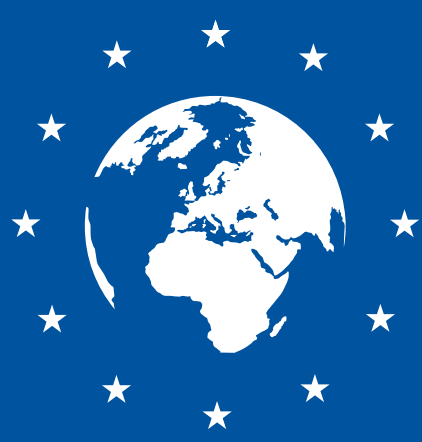




\title{
Shared Vision, Common Action: A Stronger Europe
}

\author{
A Global Strategy for the \\ European Union's Foreign And Security Policy
}

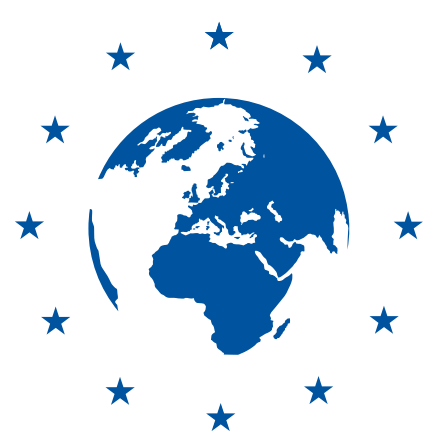





\section{Contents}

A Global Strategy for the European Union's Foreign and Security Policy: "Shared Vision, Common Action:

A Stronger Europe"

1. A Global Strategy to Promote our Citizens' Interests 13

2. The Principles Guiding our External Action 16

3. The Priorities of our External Action 18

$\begin{array}{ll}3.1 \text { The Security of Our Union } & 18\end{array}$

3.2 State and Societal Resilience to our East and South 23

3.3 An Integrated Approach to Conflicts and Crises 28

3.4 Cooperative Regional Orders $\quad 32$

3.5 Global Governance for the $21^{\text {st }}$ Century 39

4. From Vision to Action 44

$\begin{array}{ll}\text { Acknowledgements } & 53\end{array}$ 



\section{Foreword by Federica Mogherini}

High Representative

of the Union for Foreign Affairs and Security Policy

Vice-President of the European Commission

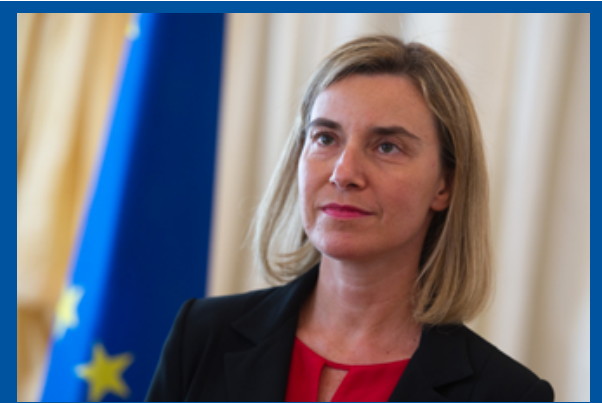

The purpose, even existence, of our Union is being questioned. Yet, our citizens and the world need a strong European Union like never before. Our wider region has become more unstable and more insecure. The crises within and beyond our borders are affecting directly our citizens' lives. In challenging times, a strong Union is one that thinks strategically, shares a vision and acts together. This is even more true after the British referendum. We will indeed have to rethink the way our Union works, but we perfectly know what to work for. We know what our principles, our interests and our priorities are. This is no time for uncertainty: our Union needs a Strategy. We need a shared vision, and common action.

None of our countries has the strength nor the resources to address these threats and seize the opportunities of our time alone. But as a Union of almost half a billion citizens, our potential is unparalleled. Our diplomatic network runs wide and deep in all corners of the globe. Economically, we are in the world's G3. We are the first trading partner and the first foreign investor for almost every country in the globe. Together we invest more in development cooperation than the rest of the world combined. It is also clear, though, that we are not making full use of this potential yet. A vast majority of our citizens understands that we need to collectively take responsibility for our role in the world. And wherever I travel, our partners expect the European Union to play a major role, including as a global security provider. We will deliver on our citizens' needs and make our partnerships work only if we act together, united. This is exactly the aim of the Global Strategy for European Foreign and Security Policy. 
"Global" is not just intended in a geographical sense: it also refers to the wide array of policies and instruments the Strategy promotes. It focuses on military capabilities and anti-terrorism as much as on job opportunities, inclusive societies and human rights. It deals with peace-building and the resilience of States and societies, in and around Europe. The European Union has always prided itself on its soft power - and it will keep doing so, because we are the best in this field. However, the idea that Europe is an exclusively "civilian power" does not do justice to an evolving reality. For instance, the European Union currently deploys seventeen military and civilian operations, with thousands of men and women serving under the European flag for peace and security - our own security, and our partners'. For Europe, soft and hard power go hand in hand.

The Strategy nurtures the ambition of strategic autonomy for the European Union. This is necessary to promote the common interests of our citizens, as well as our principles and values. Yet we know that such priorities are best served when we are not alone. And they are best served in an international system based on rules and on multilateralism. This is no time for global policemen and lone warriors. Our foreign and security policy has to handle global pressures and local dynamics, it has to cope with super-powers as well as with increasingly fractured identities. Our Union will work to strengthen our partners: We will keep deepening the transatlantic bond and our partnership with NATO, while we will also connect to new players and explore new formats. We will invest in regional orders, and in cooperation among and within regions. And we will promote reformed global governance, one that can meet the challenges of this $21^{\text {st }}$ century. We will engage in a practical and principled way, sharing global responsibilities with our partners and contributing to their strengths. We have learnt the lesson: my neighbour's and my partner's weaknesses are my own weaknesses. So we will invest in win-win solutions, and move beyond the illusion that international politics can be a zero-sum game.

All of this will make each of our Member States - and each citizen of our Union - better off. All these goals can only be achieved by a truly united and committed Europe. Joining all our cultures together to achieve our shared goals and serve our common interests is a daily challenge, but it is also our greatest strength: diversity is what makes us strong.

Yes, our interests are indeed common European interests: the only way to serve them is by common means. This is why we have a collective responsibility to make our Union a stronger Union. The people of Europe 
need unity of purpose among our Member States, and unity in action across our policies. A fragile world calls for a more confident and responsible European Union, it calls for an outward- and forward-looking European foreign and security policy. This Global Strategy will guide us in our daily work towards a Union that truly meets its citizens' needs, hopes and aspirations; a Union that builds on the success of 70 years of peace; a Union with the strength to contribute to peace and security in our region and in the whole world.

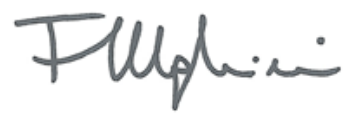

Federica Mogherini 



\section{Executive Summary}

We need a stronger Europe. This is what our citizens deserve, this is what the wider world expects.

We live in times of existential crisis, within and beyond the European Union. Our Union is under threat. Our European project, which has brought unprecedented peace, prosperity and democracy, is being questioned. To the east, the European security order has been violated, while terrorism and violence plague North Africa and the Middle East, as well as Europe itself. Economic growth is yet to outpace demography in parts of Africa, security tensions in Asia are mounting, while climate change causes further disruption. Yet these are also times of extraordinary opportunity. Global growth, mobility, and technological progress - alongside our deepening partnerships - enable us to thrive, and allow ever more people to escape poverty and live longer and freer lives. We will navigate this difficult, more connected, contested and complex world guided by our shared interests, principles and priorities. Grounded in the values enshrined in the Treaties and building on our many strengths and historic achievements, we will stand united in building a stronger Union, playing its collective role in the world.

\section{Our Shared Interests and Principles}

The European Union will promote peace and guarantee the security of its citizens and territory. Internal and external security are ever more intertwined: our security at home depends on peace beyond our borders. 
The EU will advance the prosperity of its people. Prosperity must be shared and requires fulfilling the Sustainable Development Goalsworldwide, including in Europe. A prosperous Union also hinges on an open and fair international economic system and sustainable access to the global commons. The EU will foster the resilience of its democracies. Consistently living up to our values will determine our external credibility and influence.

The EU will promote a rules-based global order. We have an interest in promoting agreed rules to provide global public goods and contribute to a peacefuland sustainable world. The EU will promote a rules-based global order with multilateralism as its key principle and the United Nations at its core.

We will be guided by clear principles. These stem as much from a realistic assessment of the current strategic environment as from an idealistic aspiration to advance a better world. Principled pragmatism will guide our external action in the years ahead.

In a more complex world, we must stand united. Only the combined weight of a true union has the potential to deliver security, prosperity and democracy to its citizens and make a positive difference in the world.

In a more connected world, the EU will engage with others. The Union cannot pull up a drawbridge to ward off external threats. To promote the security and prosperity of our citizens and to safeguard our democracies, we will manage interdependence, with all the opportunities, challenges and fears it brings about, by engaging the wider world.

In a more contested world, the EU will be guided by a strong sense of responsibility. We will engage responsibly across Europe and the surrounding regions to the east and south. We will act globally to address the root causes of conflict and poverty, and to promote human rights.

The EU will be a responsible global stakeholder, but responsibility must be shared. Responsibility goes hand in hand with revamping our external partnerships. In the pursuit of our goals, we will reach out to states, regional bodies and international organisations. We will work with core partners, like-minded countries and regional groupings. We will deepen our partnerships with civil society and the private sector as key players in a networked world. 


\section{The Priorities of our External Action}

To promote our shared interests, adhering to clear principles, the EU will pursue five priorities.

The Security of our Union. The EU Global Strategy starts at home. Our Union has enabled citizens to enjoy unprecedented security, democracy and prosperity. Yet today terrorism, hybrid threats, economic volatility, climate change and energy insecurity endanger our people and territory. An appropriate level of ambition and strategic autonomy is important for Europe's ability to promote peace and security within and beyond its borders. We will therefore enhance our efforts on defence, cyber, counterterrorism, energy and strategic communications. Member States must translate their commitments to mutual assistance and solidarity enshrined in the Treaties into action. The EU will step up its contribution to Europe's collective security, working closely with its partners, beginning with NATO.

State and Societal Resilience to our East and South. It is in the interests of our citizens to invest in the resilience of states and societies to the east stretching into Central Asia, and to the south down to Central Africa. Under the current EU enlargement policy, a credible accession process grounded in strict and fair conditionality is vital to enhance the resilience of countries in the Western Balkans and of Turkey. Under the European Neighbourhood Policy (ENP), many people wish to build closer relations with the Union: our enduring power of attraction can spur transformation in these countries. But resilience is also a priority in other countries within and beyond the ENP. The EU will support different paths to resilience, targeting the most acute cases of governmental, economic, societal and climate/energy fragility, as well as develop more effective migration policies for Europe and its partners.

An Integrated Approach to Conflicts. When violent conflicts erupt, our shared vital interests are threatened. The EU will engage in a practical and principled way in peacebuilding, and foster human security through an integrated approach. Implementing the 'comprehensive approach to conflicts and crises' through a coherent use of all policies at the EU's disposal is essential. But the meaning and scope of the 'comprehensive approach' will be expanded. The EU will act at all stages of the conflict cycle, acting promptly on prevention, responding responsibly and decisively to crises, investing in stabilisation, and avoiding premature disengagement 
when a new crisis erupts. The EU will act at different levels of governance: conflicts such as those in Syria and Libya have local, national, regional and global dimensions which must be addressed. Finally, none of these conflicts can be solved by us alone. Sustainable peace can only be achieved through comprehensive agreements rooted in broad, deep and durable regional and international partnerships, which the EU will foster and support.

Cooperative Regional Orders. In a world caught between global pressures and local pushback, regional dynamics come to the fore. Voluntary forms of regional governance offer states and peoples the opportunity to better manage security concerns, reap the economic gains of globalisation, express more fully cultures and identities, and project influence in world affairs. This is a fundamental rationale for the EU's own peace and development in the $21^{\text {st }}$ century, and this is why we will support cooperative regional orders worldwide. In different regions - in Europe; in the Mediterranean, Middle East and Africa; across the Atlantic, both north and south; in Asia; and in the Arctic - the EU will be driven by specific goals.

Global Governance for the $21^{\text {st }}$ Century. The EU is committed to a global order based on international law, which ensures human rights, sustainable development and lasting access to the global commons. This commitment translates into an aspiration to transform rather than to simply preserve the existing system. The EU will strive for a strong UN as the bedrock of the multilateral rules-based order, and develop globally coordinated responses with international and regional organisations, states and non-state actors.

\section{From Vision to Action}

We will pursue our priorities by mobilising our unparalleled networks, our economic weight and all the tools at our disposal in a coherent way. To fulfil our goals, we must collectively invest in a credible, responsive and joined-up Union.

A Credible Union. To engage responsibly with the world, credibility is vital. The EU's credibility hinges on our unity, on our many achievements, our enduring power of attraction, the effectiveness and consistency of our policies, and adherence to our values. A stronger Union also requires investing in all dimensions of foreign policy. In particular, investment in security and defence is a matter of urgency. Full spectrum defence 
capabilities are necessary to respond to external crises, build our partners' capacities, and to guarantee Europe's safety. Member States remain sovereign in their defence decisions: nevertheless, to acquire and maintain many of these capabilities, defence cooperation must become the norm. The EU will systematically encourage defence cooperation and strive to create a solid European defence industry, which is critical for Europe's autonomy of decision and action.

A Responsive Union. Our diplomatic action must be fully grounded in the Lisbon Treaty. The Common Security and Defence Policy must become more responsive. Enhanced cooperation between Member States should be explored, and might lead to a more structured form of cooperation, making full use of the Lisbon Treaty's potential. Development policy also needs to become more flexible and aligned with our strategic priorities.

A Joined-up Union. We must become more joined up across our external policies, between Member States and EU institutions, and between the internal and external dimensions of our policies. This is particularly relevant to the implementation of the Sustainable Development Goals, migration, and security, notably counter-terrorism. We must also systematically mainstream human rights and gender issues across policy sectors and institutions.

This Strategy is underpinned by the vision of and ambition for a stronger Union, willing and able to make a positive difference in the world. Our citizens deserve a true Union, which promotes our shared interests by engaging responsibly and in partnership with others. It is now up to us to translate this into action. 



\section{Shared Vision, Common Action: A Stronger Europe}

A Global Strategy for the European Union's Foreign and Security Policy

We need a stronger Europe. This is what our citizens deserve, this is what the wider world expects. We live in times of existential crisis, within and beyond the European Union. Our Union is under threat. Our European project, which has brought unprecedented peace, prosperity and democracy, is being questioned. To the east, the European security order has been violated, while terrorism and violence plague North Africa and the Middle East, as well as Europe itself. Economic growth is yet to outpace demography in parts of Africa, security tensions in Asia are mounting, while climate change causes further disruption. Yet these are also times of extraordinary opportunity. Global growth, mobility, and technological progress - alongside our deepening partnerships - enable us to thrive, and allow ever more people to escape poverty and live longer and freer lives. We will navigate this difficult, more connected, contested and complex world guided by our shared interests, principles and priorities. Grounded in the values enshrined in the Treaties and building on our many strengths and historic achievements, we will stand united in building a stronger Union, playing its collective role in the world.

\section{A Global Strategy to Promote our Citizens' Interests}

Our interests and values go hand in hand. We have an interest in promoting our values in the world. At the same time, our fundamental values are embedded in our interests. Peace and security, prosperity, democracy and a rules-based global order are the vital interests underpinning our external action. 


\section{"Our interests and values go hand in hand. We have an interest in promoting our values in the world. At the same time, our fundamental values are embedded in our interests."}

\section{Peace and Security}

The European Union will promote peace and guarantee the security of its citizens and territory. This means that Europeans, working with partners, must have the necessary capabilities to defend themselves and live up to their commitments to mutual assistance and solidarity enshrined in the Treaties.

"Europeans, working with partners, must have
the necessary capabilities to defend themselves
and live up to their commitments to mutual
assistance and solidarity enshrined in the
Treaties. Internal and external security are ever
more intertwined: our security at home entails a
parallel interest in peace in our neighbouring and
surrounding regions."

Internal and external security are ever more intertwined: our security at home entails a parallel interest in peace in our neighbouring and surrounding regions. It implies a broader interest in preventing conflict, promoting human security, addressing the root causes of instability and working towards a safer world.

\section{Prosperity}

The EU will advance the prosperity of its people. This means promoting growth, jobs, equality, and a safe and healthy environment. While a prosperous Union is the basis for a stronger Europe in the world, prosperity must be shared and requires fulfilling the Sustainable Development Goals (SDGs) worldwide, including in Europe. Furthermore, with most world growth expected to take place outside the EU in near future, trade and investment will increasingly underpin our prosperity: a prosperous Union 
hinges on a strong internal market and an open international economic system. We have an interest in fair and open markets, in shaping global economic and environmental rules, and in sustainable access to the global commons through open sea, land, air and space routes. In view of the digital revolution, our prosperity also depends on the free flow of information and global value chains facilitated by a free and secure Internet.

\section{Democracy}

The EU will foster the resilience of its democracies, and live up to the values that have inspired its creation and development. These include respect for and promotion of human rights, fundamental freedoms and the rule of law. They encompass justice, solidarity, equality, nondiscrimination, pluralism, and respect for diversity. Living up consistently to our values internally will determine our external credibility and influence.

\section{"Living up consistently to our values internally will determine our external credibility and influence."}

To safeguard the quality of our democracies, we will respect domestic, European and international law across all spheres, from migration and asylum to energy, counter-terrorism and trade. Remaining true to our values is a matter of law as well as of ethics and identity.

\section{A Rules-Based Global Order}

The EU will promote a rules-based global order with multilateralism as its key principle and the United Nations at its core. As a Union of mediumto-small sized countries, we have a shared European interest in facing the world together. Through our combined weight, we can promote agreed rules to contain power politics and contribute to a peaceful, fair and prosperous

\section{"As a Union of medium-to-small sized countries, we have a shared European interest in facing the world together."}

world. The Iranian nuclear agreement is a clear illustration of this fact. A multilateral order grounded in international law, including the principles of the UN Charter and the Universal Declaration of Human Rights, is the only guarantee 
for peace and security at home and abroad. A rules-based global order unlocks the full potential of a prosperous Union with open economies and deep global connections, and embeds democratic values within the international system.

\section{The Principles Guiding our External Action}

We will be guided by clear principles. These stem as much from a realistic assessment of the strategic environment as from an idealistic aspiration to advance a better world. In charting the way between the Scylla of

\section{"Principled pragmatism will guide our external action in the years ahead."}

isolationism and the Charybdis of rash interventionism, the EU will engage the world manifesting responsibility towards others and sensitivity to contingency. Principled pragmatism will guide our external action in the years ahead.

\section{Unity}

In a more complex world of global power shifts and power diffusion, the EU must stand united. Forging unity as Europeans - across institutions, states and peoples - has never been so vital nor so urgent. Never has our unity been so challenged. Together we will be able to achieve more than Member States acting alone or in an uncoordinated manner. There is no

\section{"Forging unity as Europeans has never been so vital nor so urgent. There is no clash between national and European interests. Our shared interests can only be served by standing and acting together."}

clash between national and European interests. Our shared interests can only be served by standing and acting together. Only the combined weight of a true union has the potential to deliver security, prosperity and democracy to its citizens and make a positive difference in the world. The interests of our citizens are best served through unity of purpose between Member 
States and across institutions, and unity in action by implementing together coherent policies.

\section{Engagement}

In a more connected world, the EU will reach out and engage with others. In light of global value chains, galloping technological advances and growing migration, the EU will participate fully in the global marketplace and co-shape the rules that govern it. The Union cannot pull up a drawbridge to ward off external threats. Retreat from the world only deprives us of the opportunities that a connected world presents.

\section{"The Union cannot pull up a drawbridge to ward off external threats. Retreat from the world only deprives us of the opportunities that a connected world presents."}

Environmental degradation and resource scarcity know no borders, neither do transnational crime and terrorism. The external cannot be separated from the internal. In fact, internal policies often deal only with the consequences of external dynamics. We will manage interdependence, with all the opportunities, challenges and fears it brings about, by engaging in and with the wider world.

\section{Responsibility}

In a more contested world, the EU will be guided by a strong sense of responsibility. There is no magic wand to solve crises: there are no neat recipes to impose solutions elsewhere. However, responsible engagement
"We will take responsibility foremost in Europe and its surrounding regions, while pursuing targeted engagement further afield. We will act globally to address the root causes of conflict and poverty, and to champion the indivisibility and universality of human rights." 
can bring about positive change. We will therefore act promptly to prevent violent conflict, be able and ready to respond responsibly yet decisively to crises, facilitate locally owned agreements, and commit long-term. We will take responsibility foremost in Europe and its surrounding regions, while pursuing targeted engagement further afield. We will act globally to address the root causes of conflict and poverty, and to champion the indivisibility and universality of human rights.

\section{Partnership}

The EU will be a responsible global stakeholder, but responsibility must be shared and requires investing in our partnerships. Co-responsibility will be our guiding principle in advancing a rules-based global order.

\section{"The EU will be a responsible global stakeholder, but responsibility must be shared and requires investing in our partnerships."}

In pursuing our goals, we will reach out to states, regional bodies and international organisations. We will work with core partners, like-minded countries and regional groupings. We will partner selectively with players whose cooperation is necessary to deliver global public goods and address common challenges. We will deepen our partnerships with civil society and the private sector as key actors in a networked world. We will do so through dialogue and support, but also through more innovative forms of engagement.

\section{The Priorities of our External Action}

To promote our shared interests, adhering to clear principles, we will pursue five broad priorities.

\subsection{The Security of Our Union}

The EU Global Strategy starts at home. Over the decades, our Union has enabled citizens to enjoy unprecedented security, democracy and prosperity. We will build on these achievements in the years ahead. Yet today terrorism, hybrid threats, climate change, economic volatility and 


\section{"The EU Global Strategy starts at home. To preserve and develop what we achieved so far, a step change is essential. We must translate our commitments to mutual assistance and solidarity into action."}

energy insecurity endanger our people and territory. The politics of fear challenges European values and the European way of life. To preserve and develop what we achieved so far, a step change is essential. To guarantee our security, promote our prosperity and safeguard our democracies, we will strengthen ourselves on security and defence in full compliance with human rights and the rule of law. We must translate our commitments to mutual assistance and solidarity into action, and contribute more to Europe's collective security through five lines of action.

\section{Security and Defence}

As Europeans we must take greater responsibility for our security. We must be ready and able to deter, respond to, and protect ourselves against external threats. While NATO exists to defend its members - most of which are European - from external attack, Europeans must be better equipped,

\section{"As Europeans we must take greater responsibil- ity for our security. We must be ready and able to deter, respond to, and protect ourselves against external threats."}

trained and organised to contribute decisively to such collective efforts, as well as to act autonomously if and when necessary. An appropriate level of ambition and strategic autonomy is important for Europe's ability to foster peace and safeguard security within and beyond its borders.

Europeans must be able to protect Europe, respond to external crises, and assist in developing our partners' security and defence capacities, carrying out these tasks in cooperation with others. Alongside external crisis management and capacity-building, the EU should also be able to assist in protecting its Members upon their request, and its institutions. 
This means living up to our commitments to mutual assistance and solidarity and includes addressing challenges with both an internal and external dimension, such as terrorism, hybrid threats, cyber and energy security, organised crime and external border management. For instance, Common Security and Defence Policy (CSDP) missions and operations can work alongside the European Border and Coast Guard and EU specialised agencies to enhance border protection and maritime security in order to save more lives, fight cross-border crime and disrupt smuggling networks.

When it comes to collective defence, NATO remains the primary framework for most Member States. At the same time, EU-NATO relations shall not prejudice the security and defence policy of those Members which are not in NATO. The EU will therefore deepen cooperation with the North Atlantic Alliance in complementarity, synergy, and full respect for the institutional framework, inclusiveness and decision-making autonomy of

\section{"The EU needs to be strengthened as a security community: European security and defence efforts should enable the EU to act autonomously while also contributing to and undertaking actions in cooperation with NATO."}

the two. In this context, the EU needs to be strengthened as a security community: European security and defence efforts should enable the EU to act autonomously while also contributing to and undertaking actions in cooperation with NATO. A more credible European defence is essential also for the sake of a healthy transatlantic partnership with the United States.

Member States need the technological and industrial means to acquire and sustain those capabilities which underpin their ability to act autonomously. While defence policy and spending remain national prerogatives, no Member State can afford to do this individually: this requires a concerted and cooperative effort. Deeper defence cooperation engenders interoperability, effectiveness, efficiency and trust: it increases the output of defence spending. Developing and maintaining defence capabilities requires both investments and optimising the use of national resources through deeper cooperation.

The EU will assist Member States and step up its contribution to Europe's security and defence in line with the Treaties. Gradual synchronisation 
and mutual adaptation of national defence planning cycles and capability development practices can enhance strategic convergence between Member States. Union funds to support defence research and technologies and multinational cooperation, and full use of the European Defence Agency's potential are essential prerequisites for European security and defence efforts underpinned by a strong European defence industry.

\section{Counter-terrorism}

Major terrorist attacks have been carried out on European soil and beyond. Increased investment in and solidarity on counter-terrorism are key. We will therefore encourage greater information sharing and intelligence cooperation between Member States and EU agencies. This entails shared alerts on violent extremism, terrorist networks and foreign terrorist fighters, as well as monitoring and removing unlawful content from the

\section{"The EU will live up to its values internally and externally: this is the strongest antidote we have against violent extremism."}

media. Alongside, the EU will support the swift recovery of Members States in the event of attacks through enhanced efforts on security of supply, the protection of critical infrastructure, and strengthening the voluntary framework for cyber crisis management. We will deepen work on education, communication, culture, youth and sport to counter violent extremism. We will work on counter-radicalisation by broadening our partnerships with civil society, social actors, the private sector and the victims of terrorism, as well as through inter-religious and inter-cultural dialogue. Most crucially of all, the EU will live up to its values internally and externally: this is the strongest antidote we have against violent extremism. We will also further develop human rights-compliant anti-terrorism cooperation with North Africa, the Middle East, the Western Balkans and Turkey, among others, and work with partners around the world to share best practices and develop joint programmes on countering violent extremism and radicalisation.

\section{Cyber Security}

The EU will increase its focus on cyber security, equipping the EU and assisting Member States in protecting themselves against cyber threats while maintaining an open, free and safe cyberspace. This entails strengthening 
the technological capabilities aimed at mitigating threats and the resilience of critical infrastructure, networks and services, and reducing cybercrime. It means fostering innovative information and communication technology (ICT) systems which guarantee the availability and integrity of data, while ensuring security within the European digital space through appropriate policies on the location of data storage and the certification of digital products and services. It requires weaving cyber issues across all policy areas, reinforcing the cyber elements in CSDP missions and operations, and further developing platforms for cooperation. The EU will support political, operational and technical cyber cooperation between Member States, notably on analysis and consequence management, and foster shared assessments between EU structures and the relevant institutions in Member States. It will enhance its cyber security cooperation with core partners such as the US and NATO. The EU's response will also be embedded in strong public-private partnerships. Cooperation and information-sharing between Member States, institutions, the private sector and civil society can foster a common cyber security culture, and raise preparedness for possible cyber disruptions and attacks.

\section{Energy Security}

The Energy Union represents an integrated effort to work on the internal and external dimensions of European energy security. In line with the goals of the Energy Union, the EU will seek to diversify its energy sources, routes and suppliers, particularly in the gas domain, as well as to promote the highest nuclear safety standards in third countries. Through our energy diplomacy, we will strengthen relations worldwide with reliable energy-producing and transit countries, and support the establishment of infrastructure to allow diversified sources to reach European markets.

\section{"Through our energy diplomacy, we will strengthen relations worldwide with reliable energy- producing and transit countries, and support the establishment of infrastructure to allow diversified sources to reach European markets."}

However, binding infrastructure agreements with third countries can have a differentiated impact on the security of supply within the Union or hinder the functioning of the internal energy market. Therefore, such 
agreements must be transparent and any new infrastructure must be fully compliant with applicable EU law, including the Third Energy Package. Internally, the EU will work on a fully functioning internal energy market, focus on sustainable energy and energy efficiency, and develop coherently reverse flow, interconnection, and liquefied natural gas (LNG) storage infrastructure.

\section{Strategic Communications}

The EU will enhance its strategic communications, investing in and joiningup public diplomacy across different fields, in order to connect EU foreign policy with citizens and better communicate it to our partners. We will improve the consistency and speed of messaging on our principles and actions. We will also offer rapid, factual rebuttals of disinformation. We will continue fostering an open and inquiring media environment within and beyond the EU, also working with local players and through social media.

\subsection{State and Societal Resilience to our East and South}

It is in the interests of our citizens to invest in the resilience of states and societies to the east stretching into Central Asia, and south down to Central Africa. Fragility beyond our borders threatens all our vital interests. By contrast, resilience - the ability of states and societies to reform, thus withstanding and recovering from internal and external crises - benefits us

\section{"It is in the interests of our citizens to invest in the resilience of states and societies to the east stretching into Central Asia, and south down to Central Africa. A resilient society featuring democracy, trust in institutions, and sustainable development lies at the heart of a resilient state."}

and countries in our surrounding regions, sowing the seeds for sustainable growth and vibrant societies. Together with its partners, the EU will therefore promote resilience in its surrounding regions. A resilient state is a secure state, and security is key for prosperity and democracy. But the reverse holds true as well. To ensure sustainable security, it is not only state 
institutions that we will support. Echoing the Sustainable Development Goals, resilience is a broader concept, encompassing all individuals and the whole of society. A resilient society featuring democracy, trust in institutions, and sustainable development lies at the heart of a resilient state.

\section{Enlargement Policy}

Any European state which respects and promotes the values enshrined in our Treaties may apply to become a Member of the Union. A credible enlargement policy grounded on strict and fair conditionality is an irreplaceable tool to enhance resilience within the countries concerned,

\section{"A credible enlargement policy represents a strategic investment in Europe's security and prosperity, and has already contributed greatly to peace in formerly war-torn areas."}

ensuring that modernisation and democratisation proceed in line with the accession criteria. A credible enlargement policy represents a strategic investment in Europe's security and prosperity, and has already contributed greatly to peace in formerly war-torn areas.

Within the scope of the current enlargement policy, the challenges of migration, energy security, terrorism and organised crime are shared between the EU, the Western Balkans and Turkey. They can only be addressed together. Yet the resilience of these countries cannot be taken for granted. The EU enjoys a unique influence in all these countries. The strategic challenge for the EU is therefore that of promoting political reform, rule of law, economic convergence and good neighbourly relations in the Western Balkans and Turkey, while coherently pursuing cooperation across different sectors.

EU policy towards the candidate countries will continue to be based on a clear, strict and fair accession process. It will focus on fundamental requirements for membership first and feature greater scrutiny of reforms, clearer reform requirements, and feedback from the European Commission and Member States, as well as local civil societies. At the same time, EU support for and cooperation with these countries must deliver concrete benefits today, and must be communicated well. This means cooperating 
on counter-terrorism, security sector reform, migration, infrastructure, energy and climate, deepening people-to-people contacts, and retailoring some of the EU's assistance with the aim of visibly improving citizens' wellbeing.

\section{Our Neighbours}

State and societal resilience is our strategic priority in the neighbourhood. Many people within the scope of the European Neighbourhood Policy (ENP) both to the east and to the south wish to build closer relations with the Union. Our enduring power of attraction can spur transformation and is not aimed against any country. Within this group are currently countries such as Tunisia or Georgia, whose success as prosperous, peaceful and stable democracies would reverberate across their respective regions. The ENP has recommitted to Eastern Partnership and southern Mediterranean countries wishing to develop stronger relations with us. We will support these countries in implementing association agreements, including Deep and Comprehensive Free Trade Areas (DCFTAs). We will also think creatively about deepening tailor-made partnerships further. Possibilities include the creation of an economic area with countries implementing DCFTAs, the extension of Trans-European Networks and the Energy Community, as well as building physical and digital connections. Societal links will also be strengthened through enhanced mobility, cultural and educational exchanges, research cooperation and civil society platforms. Full participation in EU programmes and agencies will be pursued alongside strategic dialogue with a view to paving the way for these countries' further involvement in CSDP.

Resilience is a strategic priority across the EU's east and south both in countries that want stronger ties with the EU and in those - within and beyond the ENP - that have no wish to do so. The EU will support different paths to resilience to its east and south, focusing on the most acute dimensions of fragility and targeting those where we can make a meaningful difference.

\section{Resilience in our Surrounding Regions}

The EU will pursue a multifaceted approach to resilience in its surrounding regions. While repressive states are inherently fragile in the long term, there are many ways to build inclusive, prosperous and secure societies. We will therefore pursue tailor-made policies to support inclusive and accountable 
governance, critical for the fight against terrorism, corruption and organised crime, and for the protection of human rights. Repression suffocates outlets for discontent and marginalises communities. The EU will therefore promote human rights through dialogue and support, including in the most difficult cases. Through long-term engagement, we will persistently seek to advance human rights protection. We will pursue locally owned rights-based approaches to the reform of the justice, security and defence sectors, and support fragile states in building capacities, including cyber. We will work through development, diplomacy, and CSDP, ensuring that our security sector reform efforts enable and enhance our partners' capacities to deliver security within the rule of law. We will cooperate with other international players, coordinating our work on capacity-building with the UN and NATO in particular.

"Echoing the Sustainable Development Goals,
the EU will adopt a joined-up approach to its
humanitarian, development, migration, trade,
investment, infrastructure, education, health and
research policies, as well as improve horizontal
coherence between the EU and its Member
States. We will nurture societal resilience also by
deepening work on education, culture and youth
to foster pluralism, coexistence and respect."

States are resilient when societies feel they are becoming better off and have hope in the future. Echoing the Sustainable Development Goals, the EU will adopt a joined-up approach to its humanitarian, development, migration, trade, investment, infrastructure, education, health and research policies, as well as improve horizontal coherence between the EU and its Member States. We will fight poverty and inequality, widen access to public services and social security, and champion decent work opportunities, notably for women and youth. We will foster an enabling environment for new economic endeavours, employment and the inclusion of marginalised groups. Development funds should catalyse strategic investments through public-private partnerships, driving sustainable growth, job creation, and skills and technological transfers. We will use our trade agreements to 
underpin sustainable development, human rights protection and rulesbased governance.

Societal resilience will be strengthened by deepening relations with civil society, notably in its efforts to hold governments accountable. We will reach out more to cultural organisations, religious communities, social partners and human rights defenders, and speak out against the shrinking space for civil society including through violations of the freedoms of speech and association. Positive change can only be home-grown, and may take years to materialise. Our commitment to civil society will therefore be long-term. We will nurture societal resilience also by deepening work on education, culture and youth to foster pluralism, coexistence and respect.

Finally, the EU will seek to enhance energy and environmental resilience. Energy transition is one of the major challenges in our surrounding regions, but must be properly managed to avoid fuelling social tensions. Climate change and environmental degradation exacerbate potential conflict, in light of their impact on desertification, land degradation, and water and food scarcity. Mirroring security sector reform efforts, energy and environmental sector reform policies can assist partner countries along a path of energy transition and climate action. Through such efforts, we will encourage energy liberalisation, the development of renewables, better regulation and technological transfers, alongside climate change mitigation and adaptation. We will also support governments to devise sustainable responses to food production and the use of water and energy through development, diplomacy and scientific cooperation.

\section{A More Effective Migration Policy}

A special focus in our work on resilience will be on origin and transit countries of migrants and refugees. We will significantly step up our humanitarian efforts in these countries, focusing on education, women and children. Together with countries of origin and transit, we will develop common and tailor-made approaches to migration featuring development, diplomacy, mobility, legal migration, border management, readmission and return. Through development, trust funds, preventive diplomacy and mediation we will work with countries of origin to address and prevent the root causes of displacement, manage migration, and fight trans-border crime. We will support transit countries by improving reception and asylum capacities, and by working on migrants' education, vocational training and livelihood opportunities. We must stem irregular flows by making returns more effective as well as by ensuring regular channels for human mobility. This 


\section{"Together with countries of origin and transit, we will develop common and tailor-made approaches to migration featuring development, diplomacy, mobility, legal migration, border management, readmission and return. We will work with our international partners to ensure shared global responsibilities and solidarity."}

means enhancing and implementing existing legal and circular channels for migration. It also means working on a more effective common European asylum system which upholds the right to seek asylum by ensuring the safe, regulated and legal arrival of refugees seeking international protection in the EU. At the same time, we will work with our international partners to ensure shared global responsibilities and solidarity. We will establish more effective partnerships on migration management with UN agencies, emerging players, regional organisations, civil society and local communities.

\subsection{An Integrated Approach to Conflicts and Crises}

We increasingly observe fragile states breaking down in violent conflict. These crises, and the unspeakable violence and human suffering to which they give rise, threaten our shared vital interests. The EU will engage in a practical and principled way in peacebuilding, concentrating our efforts in surrounding regions to the east and south, while considering engagement further afield on a case by case basis. The EU will foster human security through an integrated approach.

All of these conflicts feature multiple dimensions - from security to gender, from governance to the economy. Implementing a multi-dimensional approach through the use of all available policies and instruments aimed at conflict prevention, management and resolution is essential. But the scope of the 'comprehensive approach' will be expanded further. There are no quick fixes to any of these conflicts. Experience in Somalia, Mali, Afghanistan and elsewhere highlights their protracted nature. The EU will therefore pursue a multi-phased approach, acting at all stages of the conflict cycle. We will invest in prevention, resolution and stabilisation, and 
avoid premature disengagement when a new crisis erupts elsewhere. The EU will therefore engage further in the resolution of protracted conflicts in the Eastern Partnership countries. None of these conflicts plays out at a single level of governance. Conflicts such as those in Syria and Libya often erupt locally, but the national, regional and global overlay they acquire is what makes them so complex. The EU will therefore pursue a multi-level approach to conflicts acting at the local, national, regional and global levels. Finally, none of these conflicts can be solved by the EU alone. We will pursue a multi-lateral approach engaging all those players present in a conflict

"The EU will engage in a practical and principled
way in peacebuilding, concentrating our efforts in
surrounding regions to the east and south, while
considering engagement further afield on a case
by case basis. We will pursue a multi-level ap-
proach to conflicts acting at the local, national,
regional and global levels; a multi-lateral ap-
proach engaging all players present in a conflict
and necessary for its resolution."

and necessary for its resolution. We will partner more systematically on the ground with regional and international organisations, bilateral donors and civil society. Greater cooperation will also be sought at the regional and international levels. Sustainable peace can only be achieved through comprehensive agreements rooted in broad, deep and durable regional and international partnerships.

\section{Pre-emptive Peace}

It has long been known that preventing conflicts is more efficient and effective than engaging with crises after they break out. Once a conflict does erupt, it typically becomes ever more intractable over time. The EU enjoys a good record on pre-emptive peacebuilding and diplomacy. We will therefore redouble our efforts on prevention, monitoring root causes such as human rights violations, inequality, resource stress, and climate change - which is a threat multiplier that catalyses water and food scarcity, pandemics and displacement. 
Early warning is of little use unless it is followed by early action. This implies regular reporting and proposals to the Council, engaging in preventive diplomacy and mediation by mobilising EU Delegations and Special Representatives, and deepening partnerships with civil society. We must develop a political culture of acting sooner in response to the risk of violent conflict.

\section{Security and Stabilisation}

The EU will engage more systematically on the security dimension of these conflicts. In full compliance with international law, European security and defence must become better equipped to build peace, guarantee security and protect human lives, notably civilians. The EU must be able to respond rapidly, responsibly and decisively to crises, especially to help fight terrorism.

\section{"European security and defence must become better equipped to build peace, guarantee securi- ty and protect human lives, notably civilians. The EU must be able to respond rapidly, responsibly and decisively to crises, especially to help fight terrorism."}

It must be able to provide security when peace agreements are reached and transition governments established or in the making. When they are not, the EU should be ready to support and help consolidating local ceasefires, paving the way for capacity building. At the same time, through a coherent use of internal and external policies, the EU must counter the spill-over of insecurity that may stem from such conflicts, ranging from trafficking and smuggling to terrorism.

When the prospect of stabilisation arises, the EU must enable legitimate institutions to rapidly deliver basic services and security to local populations, reducing the risk of relapse into violence and allowing displaced persons to return. We will therefore seek to bridge gaps in our response between an end of violence and long-term recovery, and develop the dual - security and development - nature of our engagement.

\section{Conflict Settlement}

Each conflict country will need to rebuild its own social contract between 
the state and its citizens. The Union will support such efforts, fostering inclusive governance at all levels. When the "centre" is broken, acting only top-down has limited impact. An inclusive political settlement requires action at all levels. Through CSDP, development, and dedicated financial instruments, we will blend top-down and bottom-up efforts fostering the building blocks of sustainable statehood rooted in local agency. Working at the local level - for instance with local authorities and municipalities - can help basic services be delivered to citizens, and allows for deeper engagement with rooted civil society. Working in this direction will also improve our local knowledge, helping us distinguish between those groups we will talk to without supporting, and those we will actively support as champions of human security and reconciliation.

The EU will also foster inclusive governance at all levels through mediation and facilitation. At the same time, we will develop more creative approaches to diplomacy. This also means promoting the role of women in peace efforts - from implementing the UNSC Resolution on Women, Peace and Security to improving the EU's internal gender balance. It entails having more systematic recourse to cultural, inter-faith, scientific and economic diplomacy in conflict settings.

\section{Political Economy of Peace}

The EU will foster the space in which the legitimate economy can take root and consolidate. In the midst of violent conflict, this means ensuring humanitarian aid access to allow basic goods and services to be provided.

\section{"A political economy of peace calls for greater synergies between humanitarian and develop- ment assistance, channelling our support to provide health, education, protection, basic goods and legitimate employment."}

It also means working to break the political economy of war and to create possibilities for legitimate sustenance to exist. This calls for greater synergies between humanitarian and development assistance, channelling our support to provide health, education, protection, basic goods and legitimate employment. When the prospects for stabilisation arise, trade and development - working in synergy - can underpin long-term peacebuilding. 
Restrictive measures, coupled with diplomacy, are key tools to bring about peaceful change. They can play a pivotal role in deterrence, conflict prevention and resolution. Smart sanctions, in compliance with international and EU law, will be carefully calibrated and monitored to support the legitimate economy and avoid harming local societies. To fight the criminal war economy, the EU must also modernise its policy on export control for dual-use goods, and fight the illegal trafficking of cultural goods and natural resources.

\subsection{Cooperative Regional Orders}

In a world caught between global pressures and local pushback, regional dynamics come to the fore. As complex webs of power, interaction and identity, regions represent critical spaces of governance in a de-centred world. Voluntary forms of regional governance offer states and peoples the opportunity to better manage security concerns, reap the economic gains of globalisation, express more fully cultures and identities, and project influence in world affairs. This is a fundamental rationale for the EU's own

\section{"This cooperation is a fundamental rationale for the EU's own peace and development in the $21^{\text {st }}$ century. This is why we will promote and support cooperative regional orders worldwide, including in the most divided areas."}

peace and development in the $21^{\text {st }}$ century. This is why we will promote and support cooperative regional orders worldwide, including in the most divided areas. Regional orders do not take a single form. Where possible and when in line with our interests, the EU will support regional organisations. We will not strive to export our model, but rather seek reciprocal inspiration from different regional experiences. Cooperative regional orders, however, are not created only by organisations. They comprise a mix of bilateral, subregional, regional and inter-regional relations. They also feature the role of global players interlinked with regionally-owned cooperative efforts. Taken together these can address transnational conflicts, challenges and opportunities. In different world regions, the EU will be driven by specific goals. Across all regions, we will invest in cooperative relationships to spur shared global responsibilities. 


\section{The European Security Order}

The sovereignty, independence and territorial integrity of states, the inviolability of borders and the peaceful settlement of disputes are key elements of the European security order. These principles apply to all states, both within and beyond the EU's borders.

However, peace and stability in Europe are no longer a given. Russia's violation of international law and the destabilisation of Ukraine, on top of protracted conflicts in the wider Black Sea region, have challenged the European security order at its core. The EU will stand united in upholding international law, democracy, human rights, cooperation and each country's right to choose its future freely.

Managing the relationship with Russia represents a key strategic challenge. A consistent and united approach must remain the cornerstone of EU policy towards Russia. Substantial changes in relations between the EU and Russia are premised upon full respect for international law and the principles underpinning the European security order, including the Helsinki Final Act and the Paris Charter. We will not recognise Russia's illegal annexation of Crimea nor accept the destabilisation of eastern Ukraine. We will strengthen the EU, enhance the resilience of our eastern neighbours, and uphold their right to determine freely their approach towards the EU. At the same time, the EU and Russia are interdependent. We will therefore engage Russia to discuss disagreements and cooperate if and when our interests overlap.

\section{"Substantial changes in relations between the EU and Russia are premised upon full respect for international law. At the same time, we will engage Russia to discuss disagreements and cooperate if and when our interests overlap."}

In addition to those foreign policy issues on which we currently cooperate, selective engagement could take place over matters of European interest too, including climate, the Arctic, maritime security, education, research and cross-border cooperation. Engagement should also include deeper societal ties through facilitated travel for students, civil society and business.

Spanning the region, the EU will foster cooperation with the Council of Europe and the Organisation for Security and Cooperation in Europe. The OSCE, as a Europe-wide organisation stretching into Central Asia with a 
transatlantic link, lies at the heart of the European security order. The EU will strengthen its contribution within and its cooperation with the OSCE as a pillar of European security.

\section{A Peaceful and Prosperous Mediterranean, Middle East and Africa}

The Mediterranean, Middle East and parts of sub-Saharan Africa are in turmoil, the outcome of which will likely only become clear decades from now. Solving conflicts and promoting development and human rights in the south is essential to addressing the threat of terrorism, the challenges of demography, migration and climate change, and to seizing the opportunity of shared prosperity. The EU will intensify its support for and cooperation

\section{"We will foster dialogue and negotiation over regional conflicts such as those in Syria and Libya. On the Palestinian-Israeli conflict, the EU will work closely with the Quartet, the Arab League and all key stakeholders to preserve the pros- pect of a viable two-state solution based on 1967 lines with equivalent land swaps, and to recreate the conditions for meaningful negotiations."}

with regional and sub-regional organisations in Africa and the Middle East, as well as functional cooperative formats in the region. However, regional organisations do not address all relevant dynamics, and some reflect existing cleavages. We will therefore also act flexibly to help bridge divides and support regional players in delivering concrete results. This will be achieved by mobilising our bilateral and multilateral policies and frameworks as well as by partnering with civil societies in the region.

The EU will follow five lines of action. First, in the Maghreb and the Middle East, the EU will support functional multilateral cooperation. We will back practical cooperation, including through the Union for the Mediterranean, on issues such as border security, trafficking, counter-terrorism, nonproliferation, water and food security, energy and climate, infrastructure and disaster management. We will foster dialogue and negotiation over regional conflicts such as those in Syria and Libya. On the PalestinianIsraeli conflict, the EU will work closely with the Quartet, the Arab League 
and all key stakeholders to preserve the prospect of a viable two-state solution based on 1967 lines with equivalent land swaps, and to recreate the conditions for meaningful negotiations. The EU will also promote full compliance with European and international law in deepening cooperation with Israel and the Palestinian Authority.

Second, the EU will deepen sectoral cooperation with Turkey, while striving to anchor Turkish democracy in line with its accession criteria, including the normalisation of relations with Cyprus. The EU will therefore pursue the accession process - sticking to strict and fair accession conditionality - while coherently engaging in dialogue on counter-terrorism, regional security and refugees. We will also work on a modernised customs union and visa liberalisation, and cooperate further with Turkey in the fields of education, energy and transport.

Third, the EU will pursue balanced engagement in the Gulf. It will continue to cooperate with the Gulf Cooperation Council (GCC) and individual Gulf countries. Building on the Iran nuclear deal and its implementation, it will also gradually engage Iran on areas such as trade, research, environment, energy, anti-trafficking, migration and societal exchanges. It will deepen dialogue with Iran and GCC countries on regional conflicts, human rights and counter-terrorism, seeking to prevent contagion of existing crises and foster the space for cooperation and diplomacy .

\section{"We will deepen dialogue with Iran and GCC countries on regional conflicts, human rights and counter-terrorism, seeking to prevent contagion of existing crises and foster the space for cooperation and diplomacy. "}

Fourth, in light of the growing interconnections between North and subSaharan Africa, as well as between the Horn of Africa and the Middle East, the EU will support cooperation across these sub-regions. This includes fostering triangular relationships across the Red Sea between Europe, the Horn and the Gulf to face shared security challenges and economic opportunities. It means systematically addressing cross-border dynamics in North and West Africa, the Sahel and Lake Chad regions through closer links with the African Union, the Economic Community of Western African States (ECOWAS) and the G5 Sahel. 
Finally, we will invest in African peace and development as an investment in our own security and prosperity. We will intensify cooperation with and support for the African Union, as well as ECOWAS, the Inter-Governmental Authority on Development in eastern Africa, and the East African Community, among others. We must enhance our efforts to stimulate growth and jobs in Africa. The Economic Partnership Agreements can spur African integration and mobility, and encourage Africa's full and equitable participation in global value chains. A quantum leap in European investment in Africa is

\section{"We will invest in African peace and development as an investment in our own security and prosperity. We must enhance our efforts to stimulate growth and jobs in Africa."}

also needed to support sustainable development. We will build stronger links between our trade, development and security policies in Africa, and blend development efforts with work on migration, health, education, energy and climate, science and technology, notably to improve food security. We will continue to support peace and security efforts in Africa, and assist African organisations' work on conflict prevention, counterterrorism and organised crime, migration and border management. We will do so through diplomacy, CSDP and development, as well as trust funds to back up regional strategies.

\section{A Closer Atlantic}

The EU will invest further in strong bonds across the Atlantic, both north and south. A solid transatlantic partnership through NATO and with the United States and Canada helps us strengthen resilience, address conflicts, and contribute to effective global governance. NATO, for its members, has been the bedrock of Euro-Atlantic security for almost 70 years. It remains
"The EU will invest further in strong bonds across the Atlantic, both north and south. A solid transatlantic partnership helps us strengthen resilience, address conflicts, and contribute to effective global governance." 
the strongest and most effective military alliance in the world. The EU will deepen its partnership with NATO through coordinated defence capability development, parallel and synchronised exercises, and mutually reinforcing actions to build the capacities of our partners, counter hybrid and cyber threats, and promote maritime security.

With the US, the EU will strive for a Transatlantic Trade and Investment Partnership (TTIP). Like the Comprehensive Economic and Trade Agreement (CETA) with Canada, TTIP demonstrates the transatlantic commitment to shared values and signals our willingness to pursue an ambitious rulesbased trade agenda. On the broader security agenda, the US will continue to be our core partner. The EU will deepen cooperation with the US and Canada on crisis management, counter-terrorism, cyber, migration, energy and climate action.

In the wider Atlantic space, the Union will expand cooperation and build stronger partnerships with Latin America and the Caribbean, grounded on shared values and interests. It will develop multilateral ties with the Community of Latin American and Caribbean States (CELAC) and with different regional groupings according to their competitive advantage. We will step up political dialogue and cooperation on migration, maritime security and ocean life protection, climate change and energy, disarmament, non-proliferation and arms control, and countering organised crime and terrorism. We will pursue a free trade agreement with Mercosur, build on the Political Dialogue and Cooperation Agreement with Cuba, and invest in deeper socio-economic connections with Latin American and Caribbean countries through visa facilitation, student exchanges, twinning, research cooperation and technical projects. We will also actively support the negotiation and implementation of peace agreements in the region, as we are doing in Colombia.

\section{A Connected Asia}

There is a direct connection between European prosperity and Asian security. In light of the economic weight that Asia represents for the EU - and vice versa - peace and stability in Asia are a prerequisite for our prosperity. We will deepen economic diplomacy and scale up our security role in Asia.

The EU will engage China based on respect for rule of law, both domestically and internationally. We will pursue a coherent approach 
to China's connectivity drives westwards by maximising the potential of the EU-China Connectivity Platform, and the ASEM and EU-ASEAN frameworks. The EU will also deepen trade and investment with China, seeking a level playing field, appropriate intellectual property rights

\section{"The EU will deepen trade and investment with China, seeking a level playing field, intellectual property rights protection, greater cooperation on high-end technology, dialogue on economic reform, human rights and climate action."}

protection, greater cooperation on high-end technology, and dialogue on economic reform, human rights and climate action. In parallel, the EU will deepen its economic diplomacy in the region, working towards ambitious free trade agreements with strategic partners such as Japan and India, as well as ASEAN member states, with the goal of an eventual EU-ASEAN agreement.

We will also develop a more politically rounded approach to Asia, seeking to make greater practical contributions to Asian security. We will expand our partnerships, including on security, with Japan, the Republic of Korea, Indonesia and others. We will continue to support state-building and reconciliation processes in Afghanistan together with our regional and international partners. We will promote non-proliferation in the Korean peninsula. In East and Southeast Asia, we will uphold freedom of navigation, stand firm on the respect for international law, including the Law of the Sea and its arbitration procedures, and encourage the peaceful settlement of maritime disputes. We will help build maritime capacities and support an ASEAN-led regional security architecture. In Central and South Asia, we will deepen cooperation on counter-terrorism, anti-trafficking and migration, as well as enhance transport, trade and energy connectivity. Across the Indo Pacific and East Asian regions, the EU will promote human rights and support democratic transitions such as in Myanmar/Burma.

\section{A Cooperative Arctic}

With three Member States and two European Economic Area members being Arctic states, the EU has a strategic interest in the Arctic remaining 
a low-tension area, with ongoing cooperation ensured by the Arctic Council, a well-functioning legal framework, and solid political and security cooperation. The EU will contribute to this through enhanced work on climate action and environmental research, sustainable development, telecommunications, and search \& rescue, as well as concrete cooperation with Arctic states, institutions, indigenous peoples and local communities.

\subsection{Global Governance for the $21^{\text {st }}$ Century}

Without global norms and the means to enforce them, peace and security, prosperity and democracy - our vital interests - are at risk. Guided by the values on which it is founded, the EU is committed to a global order based on international law, including the principles of the UN Charter, which ensure peace, human rights, sustainable development and lasting access

\section{"The EU is committed to a global order based on international law, including the principles of the UN Charter. This commitment translates into an aspiration to transform rather than simply preserve the existing system."}

to the global commons. This commitment translates into an aspiration to transform rather than simply preserve the existing system. The EU will strive for a strong UN as the bedrock of the multilateral rules-based order, and develop globally coordinated responses with international and regional organisations, states and non-state actors.

\section{Reforming}

A commitment to global governance must translate in the determination to reform the UN, including the Security Council, and the International Financial Institutions (IFIs). Resisting change risks triggering the erosion of such institutions and the emergence of alternative groupings to the detriment of all EU Member States. The EU will stand up for the principles of accountability, representativeness, responsibility, effectiveness and transparency. The practical meaning of such principles will be fleshed out case-by-case. We will continue to call upon members of the UN Security 
Council not to vote against credible draft resolutions on timely and decisive action to prevent or end mass atrocities. Across multilateral fora - and in particular the UN, the IFIs and the international justice organisations - the EU will strengthen its voice and acquire greater visibility and cohesion. We will work towards an increasingly unified representation of the euro area in the International Monetary Fund.

\section{Investing}

Believing in the UN means investing in it, notably in its peacekeeping, mediation, peacebuilding and humanitarian functions. The EU and its Member States, as already the first contributor to UN humanitarian agencies, will invest even further in their work. CSDP could assist further and complement UN peacekeeping through bridging, stabilisation or other operations. The EU will also enhance synergy with UN peacebuilding efforts, through greater coordination in the planning, evolution and withdrawal of CSDP capacity-building missions in fragile settings.

\section{Implementing}

The EU will lead by example by implementing its commitments on sustainable development and climate change. It will increase climate financing, drive climate mainstreaming in multilateral fora, raise the ambition for review foreseen in the Paris agreement, and work for clean energy cost reductions. The SDGs will inform the post-Cotonou partnership

\section{"The EU will lead by example by implementing its commitments on sustainable development and climate change."}

and drive reform in development policy, including the EU Consensus on Development. Moreover, implementing the SDGs will require change across all internal and external policies, galvanising public-private partnerships, and leveraging the experience of the European Investment Bank (EIB) in providing technical assistance and building capacities in developing and middle income countries.

\section{Deepening}

As the world's largest economy, the EU is a prime mover in global trade and 
investment, areas in which rules can be deepened further. Our prosperity hinges on an open and rules-based economic system with a true level playing field, which our economic diplomacy will further promote. We will pursue comprehensive free trade agreements with the US, Japan, Mercosur, India, ASEAN and others as building blocks of global free trade. Ambitious agreements built on mutual benefits such as TTIP and CETA can promote international regulatory standards, consumer protection, as well as labour, environmental, health and safety norms. New generation trade agreements which include services, the digital economy, energy and raw materials can reduce legal fragmentation and barriers, and regulate access to natural resources. The EU will ensure that all its trade agreements are

\section{"Our prosperity hinges on an open and rules- based economic system with a true level playing field, which our economic diplomacy will further promote."}

pursued in a manner that supports returning the World Trade Organisation (WTO) to the centre of global negotiations. Connected to the EU's interest in an open and fair economic system is the need for global maritime growth and security, ensuring open and protected ocean and sea routes critical for trade and access to natural resources. The EU will contribute to global maritime security, building on its experience in the Indian Ocean and the Mediterranean, and exploring possibilities in the Gulf of Guinea, the South China Sea and the Straits of Malacca. As a global maritime security provider, the EU will seek to further universalise and implement the UN Convention on the Law of the Sea, including its dispute settlement mechanisms. We will also promote the conservation and sustainable use of marine resources and biological diversity and the growth of the blue economy by working to fill legal gaps and enhancing ocean knowledge and awareness.

\section{Widening}

We will seek to widen the reach of international norms, regimes and institutions. The proliferation of weapons of mass destruction and their delivery systems remains a growing threat to Europe and the wider world. The EU will strongly support the expanding membership, universalisation, full implementation and enforcement of multilateral disarmament, nonproliferation and arms control treaties and regimes. We will use every 


\section{"The EU will strongly support the expanding membership, universalisation, full implementa- tion and enforcement of multilateral disarma- ment, non-proliferation and arms control trea- ties and regimes. We will use every means at our disposal to assist in resolving proliferation crises, as we successfully did on the Iranian nuclear programme."}

means at our disposal to assist in resolving proliferation crises, as we successfully did on the Iranian nuclear programme. The EU will actively participate in export control regimes, strengthen common rules governing Member States' export policies of military - including dual-use - equipment and technologies, and support export control authorities in third countries and technical bodies that sustain arms control regimes. The EU will also promote the responsibility to protect, international humanitarian law, international human rights law and international criminal law. We will support the UN Human Rights Council and encourage the widest acceptance of the jurisdiction of the International Criminal Court and the International Court of Justice.

\section{Developing}

At the frontiers of global affairs, rules must be further developed to ensure security and sustainable access to the global commons. The EU will be a forward-looking cyber player, protecting our critical assets and values in the digital world, notably by promoting a free and secure global Internet. We will engage in cyber diplomacy and capacity building with our partners, and seek agreements on responsible state behaviour in cyberspace based on existing international law. We will support multilateral digital governance and a global cooperation framework on cybersecurity, respecting the free flow of information. In space, we will promote the autonomy and security of our space-based services and work on principles for responsible space behaviour, which could lead to the adoption of an international voluntary code of conduct. On energy, we will encourage multilateral mechanisms aimed at ensuring sustainable energy patterns both by developing our own sustainable policies and by deepening dialogue with major energy 
consumers and producers. On health, we will work for more effective prevention, detection and responses to global pandemics. Global rules are also necessary in fields such as biotechnology, artificial intelligence, robotics and remotely piloted systems, to avoid the related security risks and reap their economic benefits. On all such issues, the EU will promote exchanges with relevant multilateral fora to help spearhead the development of rules and build partnerships at the frontiers of global affairs.

\section{Partnering}

The EU will lead by example on global governance. But it cannot deliver alone. It will act as an agenda-shaper, a connector, coordinator and facilitator within a networked web of players. It will partner with states and organisations, but also with the private sector and civil society. On the vast majority of global governance issues, we will work with the UN as the framework of the multilateral system and a core partner for the Union,

\section{"The EU will invest in pivotal non-state actors. We will sharpen the means to protect and empower civic actors, notably human rights defenders, sustaining a vibrant civil society worldwide."}

with other core partners such as the US, with regional organisations, and with like-minded and strategic partners in Asia, Africa and the Americas. The EU will also invest in pivotal non-state actors, particularly within civil society. In spite of increasing repression, global civil society is growing and fostering new types of activism. The EU will sharpen the means to protect and empower civic actors, notably human rights defenders, sustaining a vibrant civil society worldwide.

The format to deliver effective global governance may vary from case to case. On cyber, global governance hinges on a progressive alliance between states, international organisations, industry, civil society and technical experts. On maritime multilateralism, the EU will work with the UN and its specialised agencies, NATO, our strategic partners, and ASEAN. On humanitarian action, sustainable development and climate change, the EU will partner with the UN and the G20, as well as new donors, civil society and the private sector. On counterterrorism, we will deepen dialogue with the UN, while building broad partnerships with states, regional organisations, 
civil society and the private sector on issues such as countering violent extremism and terrorist financing.

\section{From Vision to Action}

We will pursue our priorities by mobilising our unparalleled networks, our economic weight and all the tools at our disposal in a coherent and coordinated way. To fulfil our goals, however, we must collectively invest in a credible, responsive and joined-up Union.

\section{A Credible Union}

To engage responsibly with the world, credibility is essential. The EU's credibility hinges on our unity, on our many achievements, our enduring power of attraction, the effectiveness and consistency of our policies, and adherence to our values. A stronger Union requires investing in all dimensions of foreign policy, from research and climate to infrastructure and mobility, from trade and sanctions to diplomacy and development.

\section{"To engage responsibly with the world, credibility is essential. In this fragile world, soft power is not enough."}

In this fragile world, soft power is not enough: we must enhance our credibility in security and defence. To respond to external crises, build our partners' capacities and protect Europe, Member States must channel a sufficient level of expenditure to defence, make the most efficient use of

\section{"A sectoral strategy, to be agreed by the Council, should further specify the civil-military level of ambition, tasks, requirements and capability priorities stemming from this Strategy."}

resources, and meet the collective commitment of $20 \%$ of defence budget spending devoted to the procurement of equipment and Research \& Technology. Capabilities should be developed with maximum interoperability 
and commonality, and be made available where possible in support of EU, NATO, UN and other multinational efforts. While a sectoral strategy, to be agreed by the Council, should further specify the civil-military level of ambition, tasks, requirements and capability priorities stemming from this Strategy, some such areas can already be highlighted in line with commitments made by the European Council.

First, European security hinges on better and shared assessments of internal and external threats and challenges. Europeans must improve the monitoring and control of flows which have security implications. This requires investing in Intelligence, Surveillance and Reconnaissance, including Remotely Piloted Aircraft Systems, satellite communications, and autonomous access to space and permanent earth observation. As regards counter-terrorism, Member States must implement legislation concerning explosives, firearms and Passenger Name Records (PNRs), as well as invest in detection capabilities and the cross-border tracing of weapons. Second, Europeans must invest in digital capabilities to secure data, networks and critical infrastructure within the European digital space. We must develop capabilities in trusted digital services and products and in cyber technologies to enhance our resilience. We will encourage greater investments and skills across Member States through cooperative research and development, training, exercises and procurement programmes. Third, regarding high-end military capabilities, Member States need all major equipment to respond to external crises and keep Europe safe. This means having full-spectrum land, air, space and maritime capabilities, including strategic enablers.

To acquire and maintain many of these capabilities, Member States will need to move towards defence cooperation as the norm. Member States remain sovereign in their defence decisions: nevertheless, nationally-oriented

"To acquire and maintain many of these capabilities, Member States will need to move towards defence cooperation as the norm. The voluntary approach to defence cooperation must translate into real commitment. A sustainable, innovative and competitive European defence industry is essential for Europe's strategic autonomy and for a credible CSDP." 
defence programmes are insufficient to address capability shortfalls. We remain far from achieving our collective benchmarks, including 35\% of total equipment spending in collaborative procurement. The voluntary approach to defence cooperation must translate into real commitment. An annual coordinated review process at EU level to discuss Member States' military spending plans could instil greater coherence in defence planning and capability development. This should take place in full coherence with NATO's defence planning process. The European Defence Agency (EDA) has a key role to play by strengthening the Capability Development Plan, acting as an interface between Member States and the Commission, and assisting Member States to develop the capabilities stemming from the political goals set out in this Strategy.

Defence cooperation between Member States will be systematically encouraged. Regular assessments of EDA benchmarks can create positive peer pressure among Member States. Crucially, EU funding for defence research and technology, reflected first in the mid-term review of the Multiannual Financial Framework, and then in a fully-fledged programme in the next budget cycle, will prove instrumental in developing the defence capabilities Europe needs.

A sustainable, innovative and competitive European defence industry is essential for Europe's strategic autonomy and for a credible CSDP. It can also stimulate growth and jobs. A solid European defence, technological and industrial base needs a fair, functioning and transparent internal market, security of supply, and a structured dialogue with defence relevant industries. Furthermore, ensuring participation of small and medium sized enterprises (SMEs) in the defence sector can improve innovation and investment in the military technologies of tomorrow.

\section{A Responsive Union}

We live in a world of predictable unpredictability. We will therefore equip ourselves to respond more rapidly and flexibly to the unknown lying ahead. A more responsive Union requires change. We need it in diplomacy, CSDP and development, as well as investment in the knowledge base underpinning our external action.

First, our diplomatic action must be fully grounded in the Lisbon Treaty. EU foreign policy is not a solo performance: it is an orchestra which plays from the same score. Our diversity is a tremendous asset provided we stand 
united and work in a coordinated way. Cooperation between Member States can strengthen our engagement in the world. A Member State or a group of Member States who are willing and able to contribute may be invited by the High Representative (HR), under the responsibility of the Council, to implement agreed positions of the Council. The HR shall keep the Council fully informed and shall ensure consistency with agreed EU policies.

\section{"EU foreign policy is not a solo performance: it is an orchestra which plays from the same score. Our diversity is a tremendous asset provided we stand united and work in a coordinated way."}

Second, CSDP must become more rapid and effective. Europeans must be ready to rapidly respond to crises in full compliance with the UN Charter. This requires Member States to enhance the deployability and interoperability of their forces through training and exercises. We must develop the capacity for rapid response also by tackling the procedural, financial and political obstacles which prevent the deployment of the Battlegroups, hamper force generation and reduce the effectiveness of CSDP military operations. At

"We must develop the capacity for rapid response also by tackling the procedural, financial and political obstacles which prevent the deployment of the Battlegroups. Enhanced cooperation between Member States should be explored in this domain. If successful and repeated over time, this might lead to a more structured form of cooperation, making full use of the Lisbon Treaty's potential."

the same time, we must further develop our civilian missions - a trademark of CSDP - by encouraging force generation, speeding up deployment, and providing adequate training based on EU-wide curricula. A responsive CSDP also requires streamlining our institutional structure. We must strengthen operational planning and conduct structures, and build closer connections 
between civilian and military structures and missions, bearing in mind that these may be deployed in the same theatre. Enhanced cooperation between Member States should be explored in this domain. If successful and repeated over time, this might lead to a more structured form of cooperation, making full use of the Lisbon Treaty's potential.

Third, development policy will become more flexible and aligned with our strategic priorities. We reaffirm our collective commitment to achieve the $0.7 \%$ ODA/GNI target in line with DAC principles. Development funds must be stable, but lengthy programming cycles limit the timely use of EU support, and can reduce our visibility and impact. The availability of limited sums for activities on the ground, notably for conflict prevention and civil

\section{"Development policy will become more flexible and aligned with our strategic priorities."}

society support, should be made more flexible. Across the Commission, flexibility will be built into our financial instruments, allowing for the use of uncommitted funds in any given year to be carried on to subsequent years to respond to crises. This will also help fill the gaps between financial instruments and budgetary headings. In parallel, the time has come to consider reducing the number of instruments to enhance our coherence and flexibility, while raising the overall amount dedicated to development.

Responsive external action must be underpinned by a strong knowledge base. Targeted approaches to resilience, conflict prevention and resolution require deeper situational awareness. The EU will invest in the EEAS and coordinate better across institutions and Member States. Putting our diverse national cultures at the service of our shared interests is a challenge, but the pool of talent available to us is unrivalled. To make the most of this, we will invest in people, particularly those on the ground. This means equipping our delegations with the necessary expertise, including on sectoral issues and in local languages, valuing experience in and of a region, beefing up the political sections of delegations, and encouraging operational staff to use their expertise more politically. It means strengthening the participation of women in foreign policy-making. It means investing in the EU Conflict Early Warning System, and making all our external engagement conflictand rights-sensitive. We will also pursue greater information sharing and joint reporting, analysis and response planning between Member 
State embassies, EU Delegations, Commission services, EU Special Representatives and CSDP missions. We will encourage cross-fertilisation between us and regional and international organisations, civil society, academia, think tanks and the private sector. We will do so both in traditional ways - through dialogue, cooperation and support - and through innovative formats such as exchanges, embedded personnel and joint facilities, harnessing knowledge and creativity in our system.

\section{A Joined-up Union}

Finally, our external action will become more joined-up. Over the years, important steps have been taken to this effect: these include institutional innovations, such as the Lisbon Treaty's creation of the double-hatted High Representative and Vice President of the European Commission (HRVP) and the European External Action Service (EEAS). A strong EEAS working together with other EU institutions lies at the heart of a coherent EU role in the world. Efforts at coherence also include policy innovations such as the "comprehensive approach to conflicts and crises" and joint programming in development, which must be further enhanced. New fields of our joined-up external action include energy diplomacy, cultural diplomacy and economic diplomacy.

"Joint programming in development must be further enhanced. New fields of our joined-up external action include energy diplomacy, cultural diplomacy and economic diplomacy. A more prosperous Union calls for greater coordination between the EU and Member States, the EIB and the private sector. We must become more joinedup across internal and external policies."

A more prosperous Union requires economic priorities to be set in relations with all countries and regions, and integrated into the external dimensions of all internal policies. A more prosperous Union calls for greater coordination between the EU and Member States, the EIB and the private sector. The Sustainable Development Goals also represent an opportunity to catalyse such coherence. Implementing them will generate coherence between 
the internal and external dimensions of our policies and across financial instruments. It allows us to develop new ways to blend grants, loans and private-public partnerships. The SDGs also encourage us to expand and apply the principle of policy coherence for development to other policy areas, and encourage joint analysis and engagement across Commission services, institutions and Member States.

We must become more joined-up across internal and external policies. The migration phenomenon, for example, requires a balanced and human rightscompliant policy mix addressing the management of the flows and the structural causes. This means overcoming the fragmentation of external policies relevant to migration. In particular, we will develop stronger links between humanitarian and development efforts through joint risk analysis, and multiannual programming and financing. We will also make different external policies and instruments migration-sensitive - from diplomacy and CSDP to development and climate - and ensure their coherence with internal ones regarding border management, homeland security, asylum, employment, culture and education.

In security terms, terrorism, hybrid threats and organised crime know no borders. This calls for tighter institutional links between our external action and the internal area of freedom, security and justice. Closer ties will be fostered through joint Council meetings and joint task forces between the EEAS and the Commission. Defence policy also needs to be better linked to policies covering the internal market, industry and space. Member State efforts should also be more joined-up: cooperation between our law enforcement, judicial and intelligence services must be strengthened. We must use the full potential of Europol and Eurojust, and provide greater support for the EU Intelligence Centre. We must feed and coordinate intelligence extracted from European databases, and put ICT - including big data analysis - at the service of deeper situational awareness. Our citizens need better protection also in third countries through joint contingency plans and crisis response exercises between Member States.

We must become more joined-up in our security and development policies. CSDP capacity building missions must be coordinated with security sector and rule of law work by the Commission. Capacity Building for Security and Development can play a key role in empowering and enabling our partners to prevent and respond to crises, and will need to be supported financially by the EU. Our peace policy must also ensure a smoother transition from 
short-term crisis management to long-term peacebuilding to avoid gaps along the conflict cycle. Long-term work on pre-emptive peace, resilience and human rights must be tied to crisis response through humanitarian aid, CSDP, sanctions and diplomacy.

Finally, we will systematically mainstream human rights and gender issues across policy sectors and institutions, as well as foster closer coordination regarding digital matters. Greater awareness and expertise on such issues is needed within the EEAS and the Commission. Better coordination between institutions would also add consistency and spread best practices, helping us build a stronger Union and a more resilient, peaceful and sustainable world.

\section{The Way Ahead}

This Strategy is underpinned by the vision of, and ambition for, a stronger Union, willing and able to make a positive difference to its citizens and in the world. We must now swiftly translate this into action. First, we will revise existing sectoral strategies, as well as devise and implement new thematic or geographic strategies in line with the political priorities of this Strategy. Such work must begin with clear procedures and timeframes agreed promptly by all relevant players. Second, the EU Global Strategy itself will require periodic reviewing in consultation with the Council, the Commission and the European Parliament. On a yearly basis we will reflect on the state

\section{"We must now swiftly translate this vision into action."}

of play of the Strategy, pointing out where further implementation must be sought. Finally, a new process of strategic reflection will be launched whenever the EU and its Member States deem it necessary to enable the Union to navigate effectively our times. Our citizens deserve a true Union, which promotes our shared interests by engaging responsibly and in partnership with others. 



\section{Acknowledgements}

All EU Member States:

Foreign Ministers

Defense Ministers

Development Ministers

Secretaries General

COREPER

PSC

National Points of Contact

Political Directors

Defence Policy Directors

Security Directors

EUMC

European Commission:

College

Commissioners' Group on External Action

Informal Task Force

EPSC

European Parliament

EU Member States' National Parliaments

Foreign Affairs and Defence Committees

InterParliamentary Conference 
European Union Institute for Security Studies (EUISS)

European Economic and Social Committee (EESC)

European Investment Bank (EIB)

Adelphi

Amnesty International

Aspen Institute Italia

Barcelona Center for International Affairs (CIDOB)

Budapest Centre for Genocide and Atrocities Prevention

Bulgarian Diplomatic Institute

BUSINESSEUROPE

Carnegie Europe

Carnegie Washington

Central European Policy Institute (CEPI)

Central European University

Center for European Perspective Friedrich-Ebert-Stiftung

Center for European Policy Studies (CEPS)

Commission of the Bishops' Conference of the European Community (COMECE)

Compagnia di S. Paolo

CONCORD

Council for Security Cooperation in Asia Pacific (CSCAP-EU)

Crisis Management Initiative (CMI)

Danish Institute for International Studies (DIIS)

Egmont

Elcano Royal Institute

Erasmus and Erasmus Mundus Alumni

European Centre for Development Policy Management (ECPDM)

European Council on Foreign Relations (ECFR)

European Leadership Network (ELN)

European Peacebuilding Office (EPLO)

European Policy Centre (EPC)

European Security and Defence College (ESDC)

European Think Tanks Group (ETTG)

European Stability Initiative (ESI) 
European Values

EUROPEUM Institute for European Policy

Finnish Institute of International Affairs (FIIA)

Friends of Europe

Hellenic Foundation for European and Foreign Policy (ELIAMEP)

International Centre for Defence and Security (ICDS)

Institut du Développement Durable et des Relations Internationales (IDDRI)

Institut Français des Relations Internationales (IFRI)

Institute of International and European Affairs (IIEA)

Institute for Development and International Relations (IRMO)

Institute for Political Science and International Relations (ISPRI)

Institute of International Relations (IIR)

International Trade Unions Confederation (ITUC)

Istituto Affari Internazionali (IAI)

Italo-Latin America Institute (IILA)

Jean Monnet Community

Konrad Adenauer Stiftung

Latvian Institute of International Relations

London School of Economics (LSE)

National Defence Institute (IDN)

New Strategy Center (NSC)

NGO Voice

Norwegian Institute of International Affairs (NUPI)

Open Society European Policy Institute (OSEPI)

Polish Institute of International Affairs (PISM)

Stiftung Wissenschaft und Politik (SWP)

Swedish Institute for International Affairs (UI)

The Diplomatic Academy of the University of Nicosia

The German Marshall Fund (GMF)

The Hague Institute for Global Justice

Transparency International

University of Malta

Special thanks to our partners that have contributed with initiatives and ideas: Brazil, Georgia, Japan, Norway, US. 
This Strategy wouldn't have been possible without the daily work of the European External Action Service (EEAS), and in particular the Strategic Planning Division, and the tireless dedication and inspiring thinking of Nathalie Tocci. 


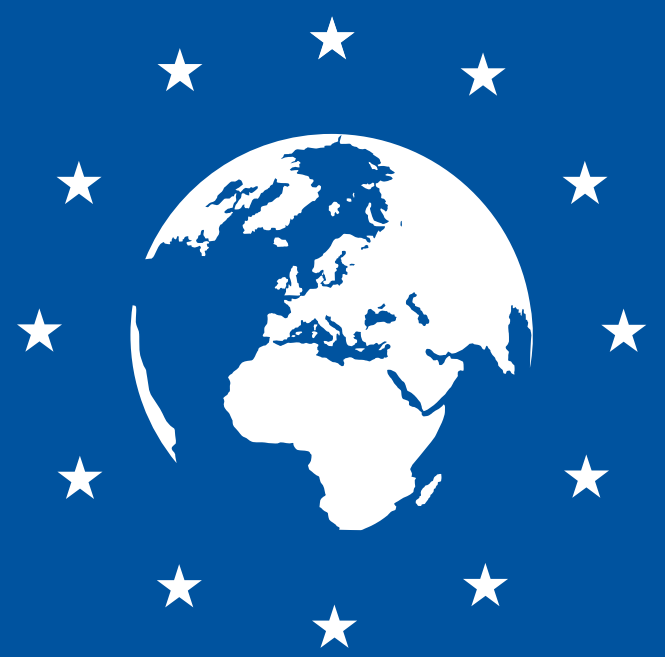

http://europa.eu/globalstrategy/en 